\title{
Defective cell mediated immunity in sarcoidosis: effect of interleukin-2
}

\author{
D J LYONS, L GAO, E B MITCHELL, D N MITCHELL \\ From the Division of Immunological Medicine, Clinical Research Centre, Harrow, and Brompton Hospital, \\ London
}

ABSTRACT Interleukin-2 has been reported to enhance the immune response in diseases character ised by defective cell mediated immunity. The effect of exogenous recombinant interleukin- 2 was studied on the proliferative and cytotoxic responses of peripheral blood mononuclear cells from 39 patients with sarcoidosis and 14 healthy control subjects. The proliferative response to purifieg protein derivative was smaller in patients than in control subjects $(\mathrm{p}<0.001)$ whereas the response to $80 \mathrm{U}$ interleukin-2 alone and to purified protein derivative and interleukin-2 did not diffe significantly between the two groups. In addition, in eight patients but no control subjects tritiated. thymidine incorporation induced by the combination of purified protein derivative and interleukinwas more than twice the sum of that induced by purified protein derivative and interleukin separately. Cytotoxic activity occurring spontaneously and induced by purified protein derivative and interleukin-2 in blood mononuclear cells was significantly less for patients with sarcoidosis than for control subjects $(\mathrm{p}<0.05$ spontaneous, $<0.001$ purified protein derivative induced, $<0.0 \AA$ interleukin induced). Synergism between antigen and interleukin did not occur with respect to tho cytotoxic response in either patients or controls. Defective interleukin-2 production may contribute to, but does not entirely explain, the functional abnormalities of peripheral blood lymphocytes frong patients with sarcoidosis.

\section{Introduction}

Sarcoidosis is characterised by granuloma formation and by the simultaneous occurrence of cellular hyperactivation and lack of responsiveness. These two aspects divide on anatomical lines. In the lung $T$ lymphocytes are activated, as indicated by unstimulated proliferation ${ }^{1}$ and release of interleukin- $2^{2}$; and alveolar macrophages are also activated, showing increased antigen presentation ${ }^{3}$ and release of $\gamma$ interferon. ${ }^{4}$ In contrast, outside the lung delayed hypersensitivity skin reactions are decreased, and peripheral blood mononuclear cells have been reported to respond poorly when stimulated with mitogens in vitro. ${ }^{5}$

Interleukin-2 is an important component in the proliferative and cytotoxic responses of lymphocytes when activated by antigens or mitogens. ${ }^{6}$ Evidence of

Address for reprint requests: Dr D J Lyons, Department of Medicine, Beaumont Hospital, PO Box 1279, Dublin 9. reduced production of interleukin-2 at sites of immunological unresponsiveness ${ }^{7}$ and increase production at sites of active disease ${ }^{2}$ led us to postulate that defective interleukin-2 production might explain. the observed discrepancy in cellular activation bet? ween blood and lung. To test this hypothesis we studied the in vitro effect of exogenous human recomo binant interleukin-2 on cytotoxic and proliferative responses of peripheral blood mononuclear cells frone. patients with sarcoidosis.

\section{Methods}

\section{STUDY POPULATIONS}

Unselected patients with sarcoidosis were studied. A里 patients had biopsy proved disease or a positive Kvein test response, or both. The disease was considered to be active if a deterioration in the chest radiograph, fall in transfer factor for carbon monoxide, or ap increase in serum angiotensin converting enzym activity had occurred in the last six months. Health control subjects were members of staff at the Clinica Research Centre, Harrow. 
Table 1 Details of the patients

\begin{tabular}{|c|c|c|c|c|c|c|c|}
\hline $\begin{array}{l}\text { Patient } \\
\text { No }\end{array}$ & Age (y) & Sex & Race & $\begin{array}{l}\text { Duration } \\
\text { of disease }\end{array}$ & $\begin{array}{l}\text { Clinical } \\
\text { details }\end{array}$ & $\begin{array}{l}\text { Disease } \\
\text { activity }\end{array}$ & Treatment \\
\hline $\begin{array}{r}1 \\
2 \\
3 \\
4 \\
5 \\
6 \\
7 \\
8 \\
9 \\
10 \\
11 \\
12 \\
13 \\
14 \\
15 \\
16 \\
17 \\
18 \\
19 \\
20 \\
21 \\
22 \\
23 \\
24 \\
25 \\
26 \\
27 \\
28 \\
29 \\
30 \\
31 \\
32 \\
33 \\
34 \\
35 \\
36 \\
37 \\
38 \\
39\end{array}$ & $\begin{array}{l}64 \\
39 \\
57 \\
62 \\
38 \\
25 \\
39 \\
41 \\
52 \\
31 \\
25 \\
35 \\
38 \\
28 \\
29 \\
30 \\
28 \\
27 \\
37 \\
34 \\
31 \\
31 \\
37 \\
31 \\
42 \\
46 \\
53 \\
57 \\
52 \\
25 \\
43 \\
52 \\
52 \\
35 \\
30 \\
49 \\
20 \\
49 \\
30\end{array}$ & $\begin{array}{l}\mathbf{F} \\
\mathbf{F} \\
\mathbf{F} \\
\mathbf{F} \\
\mathbf{F} \\
\mathbf{F} \\
\mathbf{F} \\
\mathbf{F} \\
\mathbf{F} \\
\mathbf{F} \\
\mathbf{F} \\
\mathbf{F} \\
\mathbf{M} \\
\mathbf{M} \\
\mathbf{M} \\
\mathbf{M} \\
\mathbf{M} \\
\mathbf{M} \\
\mathbf{M} \\
\mathbf{M} \\
\mathbf{M} \\
\mathbf{M} \\
\mathbf{F} \\
\mathbf{F} \\
\mathbf{F} \\
\mathbf{F} \\
\mathbf{F} \\
\mathbf{F} \\
\mathbf{F} \\
\mathbf{F} \\
\mathbf{M} \\
\mathbf{M} \\
\mathbf{M} \\
\mathbf{M} \\
\mathbf{M} \\
\mathbf{M} \\
\mathbf{M} \\
\mathbf{M}\end{array}$ & $\begin{array}{l}\text { EU } \\
\text { EU } \\
\text { EU } \\
\text { EU } \\
\text { EU } \\
\text { EU } \\
\text { EU } \\
\text { EU } \\
\text { EU } \\
\text { EU } \\
\text { EU } \\
\text { EU } \\
\text { EU } \\
\text { EU } \\
\text { EU } \\
\text { EU } \\
\text { EU } \\
\text { EU } \\
\text { EU } \\
\text { EU } \\
\text { EU } \\
\text { EU } \\
\text { EU } \\
\text { AC } \\
\text { AC } \\
\text { AC } \\
\text { A } \\
\text { AC } \\
\text { AC } \\
\text { AC } \\
\text { A } \\
\text { AC } \\
\text { AC } \\
\text { AC } \\
\text { A } \\
\text { AC } \\
\text { A } \\
\text { A } \\
\text { AC }\end{array}$ & $\begin{array}{l}18 \text { months } \\
2 \text { years } \\
1 \text { year } \\
2 \text { years } \\
3 \text { years } \\
4 \text { years } \\
1 \text { year } \\
6 \text { years } \\
1 \text { year } \\
1 \text { month } \\
9 \text { months } \\
3 \text { years } \\
1 \text { year } \\
3 \text { months } \\
6 \text { months } \\
6 \text { months } \\
2 \text { years } \\
6 \text { months } \\
3 \text { years } \\
3 \text { months } \\
1 \text { month } \\
1 \text { year } \\
3 \text { years } \\
3 \text { months } \\
1 \text { year } \\
3 \text { years } \\
2 \text { years } \\
7 \text { years } \\
10 \text { years } \\
1 \text { year } \\
1 \text { year } \\
2 \text { years } \\
2 \text { years } \\
3 \text { years } \\
2 \text { months } \\
1 \text { year } \\
1 \text { year } \\
18 \text { months } \\
6 \text { years }\end{array}$ & $\begin{array}{l}\text { BHL } \\
\text { BHL } \\
\text { L } \\
\text { C } \\
\text { PI, A } \\
\text { CNS } \\
\text { BHL } \\
\text { PI, L } \\
\text { EN, A } \\
\text { EN, BHL } \\
\text { PI } \\
\text { BHL } \\
\text { BHL, C } \\
\text { PI, A } \\
\text { BHL, PI } \\
\text { BHL } \\
\text { C, A } \\
\text { BHL } \\
\text { BHL } \\
\text { BHL, EN } \\
\text { BHL, EN } \\
\text { BHL } \\
\text { BHL } \\
\text { PI } \\
\text { PI, L } \\
\text { L } \\
\text { L } \\
\text { BHL, PI } \\
\text { PI } \\
\text { BHL, L } \\
\text { BHL, A } \\
\text { BHL, L } \\
\text { PI } \\
\text { PI } \\
\text { BHL } \\
\text { BHL } \\
\text { BHL } \\
\text { BHL, PI } \\
\text { PI }\end{array}$ & $\begin{array}{l}\text { Inactive } \\
\text { Inactive } \\
\text { Active } \\
\text { Active } \\
\text { Active } \\
\text { Active } \\
\text { Active } \\
\text { Inactive } \\
\text { Active } \\
\text { Active } \\
\text { Active } \\
\text { Active } \\
\text { Active } \\
\text { Active } \\
\text { Active } \\
\text { Active } \\
\text { Active } \\
\text { Active } \\
\text { Active } \\
\text { Active } \\
\text { Active } \\
\text { Active } \\
\text { Inactive } \\
\text { Active } \\
\text { Active } \\
\text { Active } \\
\text { Active } \\
\text { Inactive } \\
\text { Active } \\
\text { Active } \\
\text { Active } \\
\text { Inactive } \\
\text { Inactive } \\
\text { Active } \\
\text { Active } \\
\text { Inactive } \\
\text { Active } \\
\text { Active } \\
\text { Inactive }\end{array}$ & $\begin{array}{l}\text { None } \\
\text { None } \\
\text { None } \\
\text { None } \\
\text { NSAID } \\
\text { Steroid } \\
\text { None } \\
\text { None } \\
\text { None } \\
\text { NSAID } \\
\text { None } \\
\text { NSAID } \\
\text { None } \\
\text { Steroid } \\
\text { None } \\
\text { None } \\
\text { Steroid } \\
\text { None } \\
\text { None } \\
\text { Steroid } \\
\text { None } \\
\text { None } \\
\text { NSAID } \\
\text { NSAID } \\
\text { None } \\
\text { None } \\
\text { None } \\
\text { Steroid } \\
\text { None } \\
\text { None } \\
\text { None } \\
\text { Steroid } \\
\text { None } \\
\text { None } \\
\text { None } \\
\text { None } \\
\text { None } \\
\text { Steroid } \\
\text { None }\end{array}$ \\
\hline
\end{tabular}

EU-European; A-Asian; AC-Afrocaribbean; BHL-bilateral hilar lymphadenopathy; PI-pulmonary infiltrate; L-lymphadenopathy; C-skin manifestations; CNS - central nervous system affected; A-arthropathy; EN-erythema nodosum; NSAID-non-steroid antiinflammatory drug.

PROLIFERATIVE RESPONSE OF PERIPHERAL BLOOD MONONUCLEAR CELLS

Venous blood anticoagulated with heparin was diluted 1:1 with phosphate buffered saline, layered on to Ficoll-Paque (Pharmacia, Upsala, Sweden), and centrifuged at room temperature for 35 minutes at $600 \mathrm{~g}$. Peripheral blood mononuclear cells from the interface were collected, washed twice, and suspended at a concentration of $10^{6} / \mathrm{ml}$ in tissue culture medium (RPMI 1640) with $10 \%$ heat inactivated fetal calf serum, penicillin $100 \mathrm{IU} / \mathrm{ml}$, streptomycin $100 \mu \mathrm{g} / \mathrm{ml}$, and glutamine $2 \mathrm{mM}$.

The proliferative response of the peripheral blood mononuclear cells was measured by uptake of radiolabelled thymidine. The cells were suspended at $10^{6} / \mathrm{ml}$ and plated out in 96 well microtitre plates (Becton Dickinson) at $0.2 \mathrm{ml} /$ well. Cells were incubated with medium alone for control values, or were stimulated with purified protein derivative of tuberculin (PPD) $40 \mu \mathrm{g} / \mathrm{ml}$ (Serumsinstitute, Copenhagen), human recombinant interleukin-2 (IL-2) 80
U/ml (Biogen Medical Research, Switzerland), or both together. Triplicate cultures were maintained at $37^{\circ} \mathrm{C}$ in $5 \%$ carbon dioxide for seven days.

For the last six hours of culture $1 \mu \mathrm{Ci} /$ well of ${ }^{3} \mathrm{H}$-methylthymidine (specific activity $2 \mathrm{Ci} / \mathrm{nmol}$ ) (TRA 319, Amersham) was added and cells were then harvested on to glass fibre paper (Skatron AS, Norway). Filters were counted in a gamma counter (Wallac LKB, Helsinki). Results are expressed as counts per minute (cpm).

Enhancement of the proliferative response in the presence of PPD and interleukin-2 together was arbitrarily defined as a response of two or more times the sum of the separate responses to PPD and to interleukin-2.

GENERATION OF CYTOTOXIC EFFECTOR CELLS

Peripheral blood mononuclear cells were separated on Ficoll-Paque and were cultured in RPMI in flat bottomed microculture plates with $10 \%$ fetal calf serum. For spontaneous cytotoxic activity the cells 


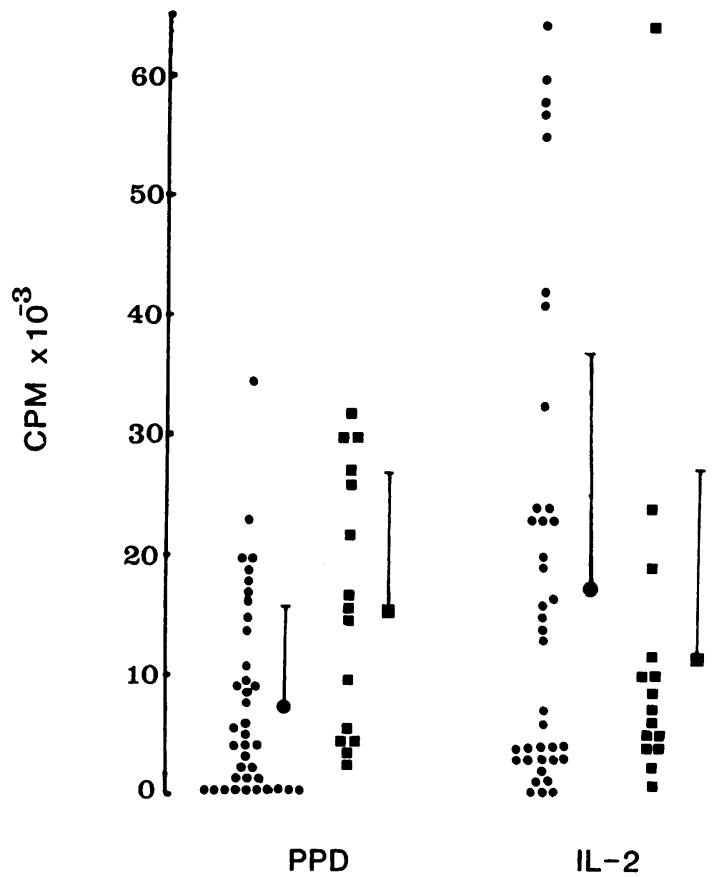

Fig 1 Proliferative response to purified protein derivative (PPD) and to interleukin-2 (IL-2) for patients (O) and controls ( $\square$ ). Group means with SD are shown (see table 2 for significant values).

were unstimulated and for antigen induced activity they were cultured in the presence of PPD $40 \mu \mathrm{g} / \mathrm{ml}$. For interleukin-2 induced cytotoxicity the cells were cultured with IL-2 $500 \mathrm{U} / \mathrm{ml}$. Cytotoxicity was measured at 24 hours.

\section{CYTOTOXICITY ASSAYS}

Cytotoxicity was assessed against T24, a human bladder carcinoma cell line, ${ }^{8}$ in a four hour chromium51 release assay. Target cells were labelled with 100 $\mu \mathrm{Ci} \mathrm{Na}{ }_{2}{ }^{51} \mathrm{CrO}_{4}$ (Amersham) at a concentration of $10^{7} /$ $\mathrm{ml}$ for 90 minutes at $37^{\circ} \mathrm{C}$, followed by four washings with balanced salt solution. Ten thousand target cells were mixed with effector cells at an effector:target ratio of 20:1. The plates were centrifuged at $100 \mathrm{~g}$ for five minutes and incubated for four hours. After incubation $100 \mu$ l of supernatant from each well was removed and counted in a gamma counter (Wallac 800). Maximum ${ }^{51} \mathrm{Cr}$ release was produced by incubation of the target cells with Triton X-100. Minimum release was produced by incubation of targets with medium alone. Results are expressed as the percentage of specific lysis, which was calculated by the formula:

$$
\frac{\text { Experimental release }- \text { minimum release }}{\text { maximum release }- \text { minimum release }} \times 100 \text {. }
$$

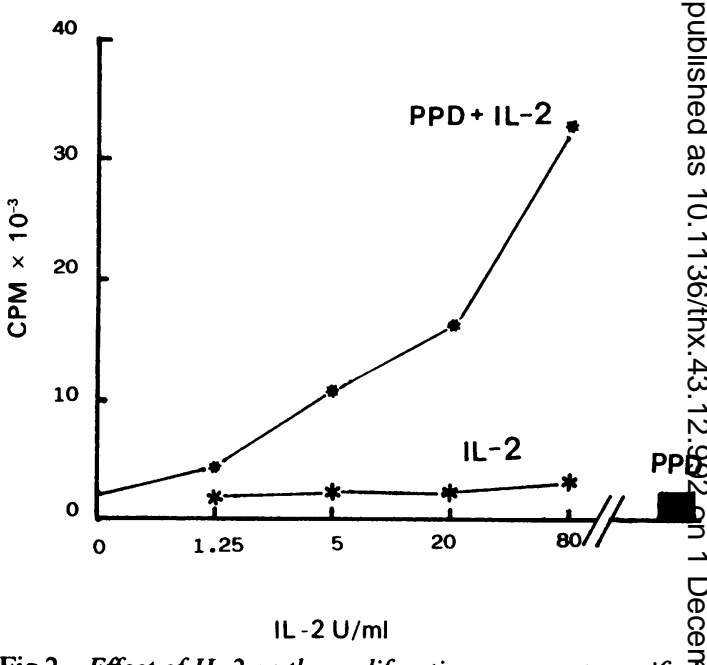

Fig 2 Effect of IL-2 on the proliferative response to purifie protein derivative (PPD): data from patient 10 (table 1), Ф showing the proliferative response to $P P D 40 \mu \mathrm{g} / \mathrm{ml}, P P D$ $40 \mu \mathrm{g} / \mathrm{ml}$ in the presence of recombinant $\mathrm{IL}-21 \cdot 25-80 \mathrm{U} / \mathrm{ml}$, and recombinant $I L-21 \cdot 25-80 \mathrm{U} / \mathrm{ml}$ alone.

STATISTICAL ANALYSIS

Data were tested for normality by using norma scores, ${ }^{9}$ and were found to be non-normally dise tributed both untransformed and after logarithmic

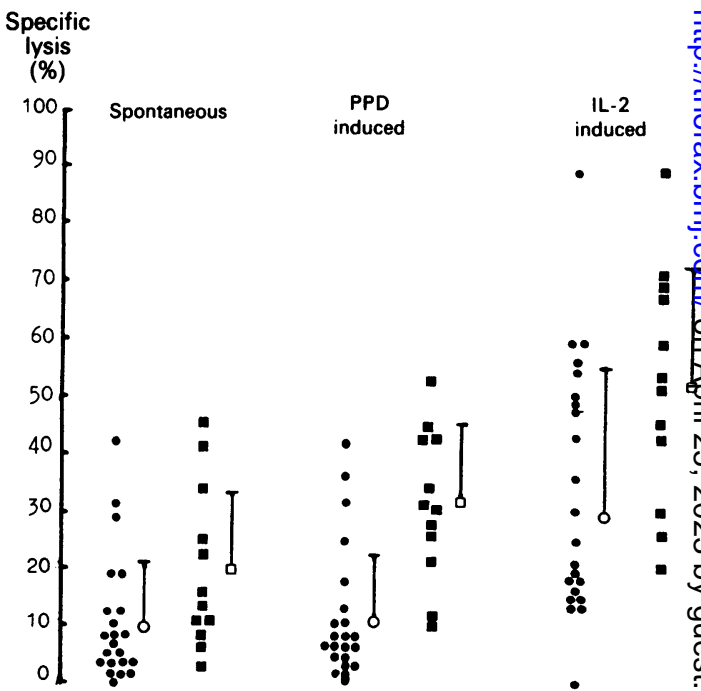

Fig 3 Cytotoxic function assessed at $24 \mathrm{~h}$ in patients with sarcoidosis ( $)$ ) and healthy controls ( $\square$ ). Cytotoxicity was unstimulated or induced by incubation with purified protein derivative (PPD) $40 \mu \mathrm{g} / \mathrm{ml}$ or by $\mathrm{IL}-2(500 \mathrm{U} / \mathrm{ml})$. All modes of cytotoxicity are significantly reduced in sarcoidosis ( $p$ unstimulated $<0.05$, purified protein derivative induced $<0.001$, interleukin-2 induced $<0.01$ ). 
Table 2 Proliferative and cytotoxic responses (mean (SD)): patients and controls

\begin{tabular}{lllll}
\hline & \multicolumn{2}{l}{ Proliferative responses $(\mathrm{cpm})$} & \multicolumn{2}{c}{ Cytotoxic response (\% specific lysis) } \\
\cline { 2 - 3 } Stimulus & Sarcoidosis $(n=39)$ & Control $(n=14)$ & Sarcoidosis $(n=22)$ & Control $(n=12)$ \\
\hline [Unstimulated] & $1011(1032)$ & $1782(1849)$ & $11(3)$ & $20(13)^{* *}$ \\
PPD & $7272(7729)$ & $15174(10874)^{* * *}$ & $12(12)$ & $32(13)^{* * *}$ \\
IL-2 & $17079(19655)$ & $11472(16105)$ & $35(22)$ & $53(21)^{* *}$ \\
IL-2 + PPD & $23998(16409)$ & $21462(12998)$ & $31(22)$ & $55(16)^{* *}$ \\
\hline
\end{tabular}

Significant difference between groups: ${ }^{*} p<0.05 ;{ }^{* *} p<0.02 ;{ }^{* *} p<0.001$. PPD-purified protein derivative; IL-2-interleukin 2 .

square root, and reciprocal transformation. The Mann-Whitney $U$ test was therefore used.

\section{Results}

\section{PROLIFERATIVE RESPONSE OF PATIENTS AND} CONTROLS

We studied 39 patients and 14 healthy control subjects. Clinical details of the patients are provided in table 1 . The proliferative response of peripheral blood mononuclear cells to purified protein derivative was significantly reduced in the patients with sarcoidosis (table 2). In contrast, proliferation of blood mononuclear cells induced by interleukin-2 did not differ significantly in the two groups (table 2). The responses of individual patients and controls are shown in figure 1 , and group data with significance values in table 2 .

Although blood mononuclear cells from some patients with sarcoidosis responded poorly to purified protein derivative and interleukin-2 separately there was a good response when the two were combined. Enhancement of response (see under "Methods") occurred in eight patients (Nos 1, 7, 8, 10, 14, 32, 33, 35 ; table 1) but in no control subjects. Enhancement of the response was dose dependent on interleukin- 2 in five of the eight patients (see fig 2), whereas in the remaining three enhancement occurred only with the highest dose of interleukin $(80 \mathrm{U} / \mathrm{ml})$.

\section{CYTOTOXIC RESPONSES}

The cytotoxic activity of unstimulated peripheral blood mononuclear cells from the patients with sarcoidosis was less than that of the control subjects (table 2, fig 3). The addition of purified protein derivative significantly increased the cytotoxicity of cells from the control subjects but not that of cells from the patients with sarcoidosis. Exogenous interleukin-2 increased cytotoxicity of cells from both groups, although interleukin induced cytotoxic activity in patients with sarcoidosis remained less than that observed in the control group. The cytotoxic response to purified protein derivative was measured in the presence or absence of interleukin in patients and controls. In both groups the response was similar to that obtained with interleukin alone (table 2). In no subject in either group was an enhancement of cytotoxic response seen in the presence of purified protein derivative and interleukin together.

\section{Discussion}

Non-specific cytotoxicity of peripheral blood lymphocytes in sarcoidosis has been the subject of studies with contradictory findings. Agostini has shown that natural killer cells, as identified by a panel of monoclonal antibodies, occur with increased frequency in peripheral blood in sarcoidosis, and that this correlates with evidence of significantly increased lysis of K-562 target cells. ${ }^{10}$ The effector population used by Agostini was depleted of adherent cells. Adherent macrophage-monocytes have previously been shown to have a suppressive effect on cellular activation in sarcoidosis. ${ }^{112}$ Hall also found increased cytotoxicity in cells from patients with sarcoidosis when he used an effector population depleted of adherent cells. ${ }^{13}$ A Japanese study showed increased natural killer activity in a functional assay. ${ }^{14}$ In contrast, Tartoff, using an unfractionated population, found that natural killer cytotoxicity and natural killer like cytotoxicity induced by antigen were reduced in women with sarcoidosis. ${ }^{15}$ Antonaci, using a phagocyte depleted effector population, found decreased cytotoxic activity. ${ }^{16}$ Recently studies from this laboratory have shown impaired interleukin-2 induced cytotoxic activity in sarcoidosis. ${ }^{17}$

The present results show that in sarcoidosis unstimulated, antigen induced, and interleukin-2 induced cytotoxicity are significantly impaired. Although extrapolation from in vitro to in vivo studies must be regarded with caution, a defect in cytotoxic function may be relevant to the increased incidence of lymphomas ${ }^{18}$ occurring in sarcoidosis.

In this study the proliferative response of the patients with sarcoidosis to purified protein derivative was clearly impaired, being less than half that of controls. In the presence of exogenous interleukin-2, however, an enhancement of proliferative response was seen in some patients. A striking example is illustrated in figure 2 . In some cases this enhancement appeared to represent a synergistic effect between antigen and interleukin-2, which was dose dependent on interleukin. The magnitude of this effect varied 
greatly. Our impression was that enhancement was more likely to occur in subjects with a low response to both reagents when given separately, though this could not be shown statistically. Skin sensitivity to tuberculin was not assessed routinely at the time of study and we cannot therefore say how it may relate to the phenomenon of in vitro enhancement.

In diseases characterised by immunological unresponsiveness, interleukin- 2 has been shown to enhance cellular responses in vitro. ${ }^{19-24}$ It has been suggested that exogenous interleukin-2 compensates for poor endogenous interleukin-2 production, and therefore restores proliferative responses. ${ }^{2021}$ The same phenomenon, however, occurs in apparently normal subjects. ${ }^{1925}$ An alternative explanation might be that interleukin-2 acts by antagonising the production or action of other inhibitory molecules, such as prostaglandins of the E series. Further studies are required to test this hypothesis. Evidence from the present study shows that enhancement of antigen induced proliferative responses in the presence of interleukin occurs only in a few sarcoidosis patients. Consequently, although a deficiency of interleukin-2 production may be a contributing factor in some patients, it is unlikely to account for the "immunological unresponsiveness" observed in patients.

We wish to thank Biogen Medical Research, Switzerland, for kindly supplying the recombinant interleukin-2 used in these experiments. We thank Drs M Malkovsky and G L Asherson for advice and comments, Dr Caroline Doré for statistical advice, and Miss Ailish O'Douoghue for preparing the manuscript. L G was supported during these studies by World Health Organisation and Wellcome Trust fellowships.

\section{References}

1 Crystal R, Roberts C, Hunninghake G, Gadek J, Fulmer J, Line B. Pulmonary sarcoidosis: a disease characterised and perpetuated by activated lung T-lymphocytes. Ann Intern Med 1981;94:73-94.

2 Hunninghake GW, Gadek JE, Young RC, Kawanami O, Ferrans VJ, Crystal RG. Mechanisms of granuloma formation in pulmonary sarcoidosis by $\mathrm{T}$-lymphocytes within the lung. $N$ Engl J Med 1980;302:594-8.

3 Venet A, Hance C, Saltini C, Robinson B. Enhanced alveolar-macrophage mediated antigen induced $T$ lymphocyte proliferation in sarcoidosis. $J$ Clin Invest 1985;75:293-301.

4 Robinson B, McLemore T, Crystal R. Gamma interferon is spontaneously released by alveolar macrophages in patients with pulmonary sarcoidosis. J Clin Invest 1985;75:1488-95.

5 Pasquali JL, Godin D, Urlacher A, Pelletier A, Pauli G,
Storck D. Abnormalities of in vitro responses tक्ष polyclonal activation of peripheral blood lymphocytes of patients with active sarcoidosis. Eur J Clin Inves 1985;117:55-62.

6 Welte K, Andreeff M, Platzer E, Holloway K, Rubin BY Moore MA, Mertelsmann R. Interleukin-2 regulates s the expression of Tac antigen on peripheral blood $\mathrm{T} \overrightarrow{0}$ lymphocytes. J Exp Med 1984;160:1390-403.

7 Agostini C, Semenzato G, Zambello R, et al. Impairedtu production of Interleukin-2 in peripheral blood of patients with sarcoidosis. Boll Inst Sieroter Milan, 1985;64:226-31.

8 Malkovsky M, Bubenik J. Human urinary bladdef carcinoma cell line (T24) in long-term culture $\vec{N}$ chromosomal studies on a wild population and derivede sublines.

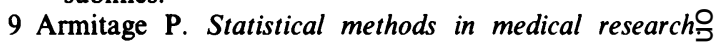
Oxford: Blackwell, 1971.

10 Agostini C, Trentin I, Zambello R, et al. Phenotypica and functional analysis of natural killer cells in sar尺 coidosis. Clin Immunol Immunopathol 1985;37:262-75孚

11 Goodwin J, De Horatius R, Israel H, Peake G, Messne R. Suppressor cell function in sarcoidosis. Ann Intern Med 1979;90:169-73.

12 Muraguchi A, Tachibana T, Miki Y, et al. Depresse $\mathscr{\infty}_{0}^{\circ}$ functions of $T$ cells and the presence of suppresso macrophages in patients with sarcoidosis. Clino Immunol Immunopathol 1982;23:189-201.

13 Hall T, Hudspith B, Johnson McI, Brostoff N. Increase $\underset{\varnothing}{ }$ natural killer cell activity in sarcoidosis. Int Arch Allergy Appl Immun 1987;82:10-6.

14 Ina Y, Yamamoto M, Takada K, et al. Natural killer cells in sarcoidosis. Nippon Kyobu Shikkan Gakkai Zassh 1982;20:189-92.

15 Tartof D, Curran JJ, Yang SL, Livingston C. NK ce据 activity and skin test antigen stimulation of NK like. CMC in vitro are decreased to different degrees if pregnancy and sarcoidosis. Clin Exp Immunof 1984;57:502-10.

16 Antonaci S, Moretti A, Bonomo L. Natural and antibody-dependent cellular cytotoxicity in patients with active sarcoidosis. Allergol Immunopathof 1983;11:40-6.

17 Jira M, Malkovsky M, Denman M, et al. Lymphokineo activated killer cell activity in rheumatoid arthritis? Clin Exp Immunol 1987;68:535-42.

18 Brincker $\mathrm{H}$. The sarcoidosis-Lymphoma syndrome. $\mathrm{Br}$ Cancer 1986;54:467-73.

19 Barnass S, Mace J, Steele J, et al. Prevalence and specificity of the enhancing effect of three types of interleukin-2 on $T$ cell responsiveness in $9 \mathrm{~W}$ lepromatous patients of mixed ethnic origin. Clin Exy Immunol 1986;64:41-9.

20 Emery P, Panayi GS, Nouri AM. Interleukin-2 reverse deficient cell mediated immune responses in rheumatoid arthritis. Clin Exp Immunol 1984;57. 123-9.

21 López-Botet M, Fontán G, Garcia Rodriguez MC, D⿳亠丷厂 Landázuri MO. Relationship between IL-2 synthes尺 and the proliferative response to PHA in differea primary immunodeficiencies. J Immunol 1982 128:679-83. Neoplasma 24:319-26. 
22 Antonacci A, Calvano S, Reaves L, et al. Autologous and allogenic mixed lymphocyte responses following thermal injury in man: the immunomodulatory effects of interleukin 1 , interleukin 2 and a prostaglandin inhibitor WY-18251. Clin Immunol Immunopathol 1984;30:304-20.

23 Ciobanu N, Welte K, Kruger G, et al. Defective T-cell response to PHA and mitogenic monoclonal antibodies in male homosexuals with acquired immunodeficiency syndrome and its in vitro correction by interleukin-2. J Clin Immunol 1983;3:332-40.
24 Welte K, Ciobanu N, Moore MA, Gulati S, O'Reilly RJ, Mertelsman R. Defective interleukin-2 production in patients after bone marrow transplantation and in vitro restoration of defective $\mathrm{T}$ lymphocyte proliferation by highly purified interleukin-2. Blood 1984;64:380.

25 Vismara D, Lombardi G, Piccolella E, Collizzi V. Dissociation between interleukin-1 and interleukin-2 production in proliferative response to microbial antigens: restorative effect of exogenous interleukin-2. Infect Immun 1985;49:298-303. 